\title{
Cadmium toxicity in plants
}

\author{
María P. Benavides, Susana M. Gallego and María L. Tomaro*
}

Departamento de Química Biológica, Facultad de Farmacia y Bioquímica, Universidad de Buenos Aires, Junín 956 (1113) Buenos Aires, Argentina.*Corresponding author: ptomaro@ffyb.uba.ar

Heavy metals are important environmental pollutants and their toxicity is a problem of increasing significance for ecological, evolutionary, nutritional, and environmental reasons. Plants posses homeostatic cellular mechanisms to regulate the concentration of metal ions inside the cell to minimize the potential damage that could result from the exposure to nonessential metal ions. This paper summarizes present knowledge in the field of higher plant responses to cadmium, an important environmental pollutant. Knowledge concerning metal toxicity, including mechanisms of cadmium homeostasis, uptake, transport and accumulation are evaluated. The role of the cell wall, the plasma membrane and the mycorrhizas, as the main barriers against cadmium entrance to the cell, as well as some aspects related to phytochelatin-based sequestration and compartmentalization processes are also reviewed. Cadmium-induced oxidative stress was also considered as one of the most studied topics of cadmium toxicity.

Key words: cadmium, heavy metals, metal toxicity, phytochelatins, oxidative stress.

Toxicidade de cádmio em plantas: Metais pesados são importantes poluentes ambientais a sua toxicidade é um problema de importância crescente por razões ecológicas, evolucionárias, nutricional e ambiental. Plantas possuem mecanismos celulares homeostáticos para regular a concentração de íons metálicos dentro das células, para minimizar o dano potencial que poderia resultar pela exposição a íons metálicos não essenciais. Este trabalho resume o presente conhecimento na area de respostas de plantas ao cádmio, um importante poluente ambiental. Conhecimento relativo a toxicidade pelo metal, incluindo mecanismos de homeostase de cádmio, absorção, transporte e acúmulo são avaliados. O papel da parede celular, membrana plasmática e micorrizas, como barreiras principais contra a entrada de cádmio na célula, assim como aspectos relacionados ao seqüestro por fitoquelatinas e compartimentalização são revistos. Estresse oxidativo induzido por cádmio é também considerado como um dos tópicos mais estudados na toxicidade por este metal pesado.

Palavras-chave: cádmio, estresse oxidativo, fitoquelatinas, metais pesados, toxicidade por metais.

\section{INTRODUCTION}

Environmental pollution by metals became extensive as mining and industrial activities increased in the late $19^{\text {th }}$ and early $20^{\text {th }}$ century. The current worldwide mine production of $\mathrm{Cu}, \mathrm{Cd}, \mathrm{Pb}$, and $\mathrm{Hg}$ is considerable (Pinto et al., 2004). These pollutants, ultimately derived from a growing number of diverse anthropogenic sources (industrial effluents and wastes, urban runoff, sewage treatment plants, boating activities, agricultural fungicide runoff, domestic garbage dumps, and mining operations), have progressively affected more and more different ecosystems (Macfarlane and Burchett, 2001).
Metal toxicity and tolerance in plants is a subject that has been broadly reviewed on several occasions over the last 30 years (Brown and Jones, 1975; Foy et al., 1978; Ernst et al., 1992; Das et al., 1997; Sanitá di Toppi and Gabrielli, 1999; Hall, 2002; Clemens et al., 2002). Fifty-three of the ninety naturally occurring elements are heavy metals (Weast, 1984). Among these metals, Fe, Mo and Mn are important as micronutrients, while $\mathrm{Zn}, \mathrm{Ni}, \mathrm{Cu}, \mathrm{Co}$, $\mathrm{Va}$ and $\mathrm{Cr}$ are toxic elements, with high or low importance as trace elements. $\mathrm{Ag}, \mathrm{As}, \mathrm{Hg}$, $\mathrm{Cd}, \mathrm{Pb}$ and $\mathrm{Sb}$ have no known function as nutrients and seem to be more or less toxic to plants and microorganisms (Niess, 
1999). The presence of both essential and non essential heavy metals in the atmosphere, soil and water, in excessive amounts, can cause serious problems to all organisms. Knowledge of metal-plant interactions is important for the safety of the environment, but also for reducing the risks associated with the introduction of trace metals into the food chain.

\section{Heavy metals toxicity}

The toxicity produced by transition metals generally involves neurotoxicity, hepatotoxicity and nephrotoxicity (Stohs and Bagchi, 1995). Differences in solubility, absorbability, transport and chemical reactivity in these metals will lead to specific differences in toxicity within the body (Stohs and Bagchi, 1995). The chemical form of heavy metals in soil solution is dependant of the metal concerned, $\mathrm{pH}$ and the presence of other ions (Das et al., 1997). The toxicity symptoms observed in plants in the presence of excessive amounts of heavy metals may be due to a range of interactions at the cellular level (Hall, 2002). Toxicity may result from the binding of metals to sulphydryl groups in proteins, leading to an inhibition of activity or disruption of structure (Van Assche and Clijters, 1990). Enzymes are one of the main targets of heavy metal ions and prolonged exposure of soils to heavy metals results in marked decreases in soil enzymes activity (Tyler et al., 1989). Metal interaction with ligand groups of enzymes largely defines their toxicity, and the inhibition of enzymes may be due to masking of catalytically active groups or protein denaturation (Das et al., 1997). In addition, heavy metal excess may stimulate the formation of free radicals and reactive oxygen species (Dietz et al., 1999; Gallego et al., 1996; Groppa et al., 2001; Sandalio et al., 2001; Fornazier et al., 2002). In order to cope with highly toxic metals, or to maintain the level of essential metals within physiological ranges, plants have evolved complex mechanisms that serve to control the uptake, accumulation and detoxification of metals.

\section{Cadmium toxicity in higher plants}

Cadmium is a non-essential element that negatively affects plant growth and development. It is released into the environment by power stations, heating systems, metal-working industries or urban traffic. It is widely used in electroplating, pigments, plastic stabilizers and nickel-cadmium batteries (Sanitá di Toppi and Gabrielli, 1999). It is recognized as an extremely significant pollutant due to its high toxicity and large solubility in water (Pinto et al., 2004). Genotoxicity and ecotoxicity of cadmium in animals have been also re- ported (Degreave, 1981; Bhattacharya and Chaudhuri, 1995). Important sources of cadmium input to the marine environment include atmospheric deposition, domestic waste water and industrial discharges. Baker et al. (1990) reported that $\mathrm{Cd}$ never occurs in isolation in natural environments, but mostly as a 'guest' metal in $\mathrm{Pb}: \mathrm{Zn}$ mineralization. Wagner (1993) estimated that non-polluted soil solutions contain $\mathrm{Cd}$ concentrations ranging from 0.04 to $0.32 \mathrm{mM}$. Soil solutions which have a $\mathrm{Cd}$ concentration varying from 0.32 to about $1 \mathrm{mM}$ can be regarded as polluted to a moderate level (Sanitá di Toppi and Gabrielli, 1999). Regarding its potential toxicity for soil organisms and soil microbial processes, Duxbury (1985) classified Cd as an element of "intermediate" toxicity. Although the toxic effects of cadmium on biological systems have been reported by several authors (Bingham et al., 1976; Mukherjee et al., 1984; Obata and Umebayashi, 1997; Das et al., 1997; Sanitá di Toppi and Gabrielli, 1999), the mechanisms of Cd toxicity are not completely understood yet. Cadmium can alter the uptake of minerals by plants through its effects on the availability of minerals from the soil, or through a reduction in the population of soil microbes (Moreno et al., 1999). Stomatal opening, transpiration, and photosynthesis have been reported to be affected by cadmium in nutrient solutions, but the metal is taken up into plants more readily from nutrient solutions than from soil. (Sanitá di Toppi and Gabrielli, 1999). Chlorosis, leaf rolls and stunting are the main and easily visible symptoms of cadmium toxicity in plants. Chlorosis may appear to be Fe deficiency (Haghiri, 1973), phosphorous deficiency or reduce Mn transport (Godbold and Hutterman, 1985). The inhibition of root $\mathrm{Fe}(\mathrm{III})$ reductase induced by $\mathrm{Cd}$ led to $\mathrm{Fe}$ (II) deficiency, and it seriously affected photosynthesis (Alcantara et al., 1994). In general, Cd has been shown to interfere with the uptake, transport and use of several elements (Ca, Mg, P and K) and water by plants (Das et al., 1997). Cd also reduced the absorption of nitrate and its transport from roots to shoots, by inhibiting the nitrate reductase activity in the shoots (Hernandez et al., 1996). Appreciable inhibition of the nitrate reductase activity was also found in plants of Silene cucubalus (Mathys, 1975). Nitrogen fixation and primary ammonia assimilation decreased in nodules of soybean plants during Cd treatments (Balestrasse et al., 2003). Metal toxicity can affect the plasma membrane permeability, causing a reduction in water content; in particular $\mathrm{Cd}$ has been reported to interact with the water balance (Barceló et al., 1986; Poschenrieder et al., 1989; Costa and Morel, 1994). Cadmium treatments have been shown to reduce ATPase ac- 
tivity of the plasma membrane fraction of wheat and sunflower roots (Fodor et al., 1995). Cadmium produces alterations in the functionality of membranes by inducing lipid peroxidation (Fodor et al., 1995), and disturbances in chloroplast metabolism by inhibiting chlorophyll biosynthesis and reducing the activity of enzymes involved in $\mathrm{CO}_{2}$ fixation (Stobart et al., 1985; De Filippis and Ziegler, 1993).

Several studies have suggested that an oxidative stress could be involved in $\mathrm{Cd}$ toxicity, by either inducing oxygen free radical production, or by decreasing enzymatic and nonenzymatic antioxidants (Somashekaraiah et al., 1992; Stohs and Bagchi, 1995; Shaw, 1995; Gallego et al., 1996; Sandalio et al., 2001; Balestrasse et al., 2001; Fornazier et al., 2002; Cho and Seo, 2004). The accelerated senescence observed in nodules of soybean plants treated with $\mathrm{Cd}$ has been attributed to the oxidative stress generated by the metal (Balestrasse et al., 2004).

\section{Cadmium homeostasis}

The sensitivity of plants to heavy metals depends on an interrelated network of physiological and molecular mechanisms that includes uptake and accumulation of metals through binding to extracellular exudates and cell wall, complexation of ions inside the cell by various substances, for example, organic acids, amino acids, ferritins, phytochelatins, and metallothioneins; general biochemical stress defense responses such as the induction of antioxidative enzymes and activation or modification of plant metabolism to allow adequate functioning of metabolic pathways and rapid repair of damaged cell structures (Verkleij and Schat, 1990; Prasad, 1999; Sanita di Toppi and Gabrielli, 1999; Hall, 2002; Cho et al., 2003).

\section{Cadmium mobilization, uptake and transport}

The bioavailability of some metals is limited because of low solubility in oxygenated water and strong binding to soil particles. Both the acidification of the rhizosphere and the exudation of carboxylates are considered potential targets for enhancing metal accumulation (Clemens et al., 2002). The degree to which higher plants are able to take up $\mathrm{Cd}$ depends on its concentration in the soil and its bioavailability, modulated by the presence of organic matter, $\mathrm{pH}$, redox potential, temperature and concentrations of other elements. With the exception of $\mathrm{Fe}$, which is solubilized by either reduction to $\mathrm{Fe}(\mathrm{II})$ or extrusion of $\mathrm{Fe}$ (III)-chelating phytosiderophores (Hirsch, 1998), little is known about active mobilization of trace elements by plant roots. In particular, the uptake of $\mathrm{Cd}$ ions seems to be in competition for the same transmembrane carrier with nutrients, such as $\mathrm{K}, \mathrm{Ca}, \mathrm{Mg}, \mathrm{Fe}, \mathrm{Mn}, \mathrm{Cu}, \mathrm{Zn}, \mathrm{Ni}$ (Clarkson and Luttge, 1989; Rivetta et al., 1997). The cell membrane plays a role in metal homeostasis, preventing or reducing entry into the cell. However, examples of exclusion or reduced uptake mechanisms in higher plants are limited. Cadmium is one of the most dangerous metals due to its high mobility and the small concentration at which its effects on plants begin to appear (Barceló and Poschenrieder, 1990). The apoplast continuum of the root epidermis and cortex is readily permeable for solutes. The cell walls of the endodermal cell layer act as a barrier for apoplastic diffusion into the vascular system. In general, solutes have to be taken up into the root symplasm before they can enter the xylem (Tester and Leigh, 2001). Subsequent to metal uptake into the root symplasm, three processes govern the movement of metals from the root into the xylem: sequestration of metals inside root cells, symplastic transport into the stele and release into the xylem (Clemens et al., 2002). The membrane potential, which is negative on the inside of the plasma membrane and might exceed $-200 \mathrm{mV}$ in root epidermal cells, provides a strong driving force for the uptake of cations through secondary transporters (Hirsch et al., 1998).

Despite the different mobility of metal ions in plants, the metal content is generally greater in roots than in the aboveground tissues (Ramos et al., 2002). In most environmental conditions, $\mathrm{Cd}$ enters first the roots, and consequently they are likely to experience $\mathrm{Cd}$ damage first (Sanitá di Toppi and Gabrielli, 1999). Cd easily penetrates the root through the cortical tissue and is translocated to the above-ground tissues (Yang et al., 1998). As soon as Cd enters the roots, it can reach the xylem through an apoplastic and/or a symplastic pathway (Salt et al., 1995a), complexed by several ligands, such as organic acids and/or phytochelatins (Senden et al., 1992, 1994; Salt et al., 1995b). Normally, Cd ions are mainly retained in the roots, and only small amounts are transported to the shoots (Cataldo et al., 1983). In general, the content of $\mathrm{Cd}$ in plants decreases in the order: roots $>$ stems $>$ leaves $>$ fruits $>$ seeds (Blum, 1997). Moral et al. (1994) reported that $\mathrm{Cd}$ was easily transported to the aerial parts of tomato plants but was not detected in fruits. It has recently been hypothesized that $\mathrm{Cd}$ accumulation in developing fruits could occur via phloem-mediated transport (Hart et al., 1998). Hinesly et al. (1984) reported that soil $\mathrm{pH}$ greatly influences Cd uptake and transportation in corn while Street et al. (1977) reported that uptake of $\mathrm{Cd}$ by corn was lower in acid soils with high organic matter content. Cadmium concentrations 
in maize and ryegrass were negatively related to the product of cadmium in soil and pH (Tudoreanu and Phillips, 2004). A positive coefficient between soil $\mathrm{pH}$ and cadmium in ryegrass may derive from ionic competition, for example, sodium has been demonstrated to increase plant cadmium (Chiy and Phillips, 1999).

With the exception of the recently described Cd-carbonic anhydrase of marine diatoms (Lane and Morel, 2000), no biological function has been reported to date for the metals $\mathrm{Pb}$ and $\mathrm{Cd}$. Thus, it is unlikely that metal transporters with specificities for the respective metal cations exist (Clemens, 2001). However, these cations without specific metal transporters are likely to enter cells through cation transporters with broad substrate specificity (Clemens, 2001). Cd and $\mathrm{Zn}$ have been found to be co-accumulated in aerial parts of Arabidopsis halleri (Bert et al., 2003) plants. This shows that $\mathrm{Cd}$ and $\mathrm{Zn}$ uptake are genetically correlated, suggesting that the metals are taken up (partly, at least) by the same transporter(s) or that their transporters, when different, are controlled by common regulators. Arabidopsis halleri L., previously known as Cardaminopsis halleri L. Hayek, is one of the two species known to hyperaccumulate Cd (Brooks, 1998; Küpper et al., 2000), is also a zinc (Zn) hyperaccumulator and usually occurs on $\mathrm{Zn}, \mathrm{Cd}$ and $\mathrm{Pb}$ contaminated sites (Bert et al., 2003). Differences in grain $\mathrm{Cd}$ accumulation between two wheat species (Triticum aestivum and Triticum turgidum var. durum) may not only result from differences in root $\mathrm{Cd}$ influx, but seem to be associated with differences in plant-internal Cd allocation (Hart et al., 1998).

Several cation transporters have been identified in recent years with the use of molecular techniques, largely owing to the complementation of Saccharomyces cerevisiae mutants (Clemens, 2001). Most of the transporters thought to be involved in the uptake of micronutrients are in the ZIP (ZRT, IRT-like protein) and the Nramp (natural resistance-associated macrophage protein) family (Guerinot, 2000; Williams et al., 2000). Recently, several plant transporters have been identified that show affinity for both $\mathrm{Zn}$ and $\mathrm{Cd}$. By complementation of a yeast $\mathrm{Zn}$-transport defective mutant with a T. caerulescens cDNA library, Lasat et al. (2000) cloned the ZNT1 cDNA, which encodes a high affinity Zn transporter. However, ZNT1 can also mediate low affinity Cd transport (Lasat et al., 2000; Pence et al., 2000). Based on the study of two T. caerulescens ecotypes, Lombi et al. (2000) suggested that $\mathrm{Cd}$ may be transported in the low $\mathrm{Cd}$ accumulation ecotype via ZNT1 but, conversely, that Cd may be mediated in the high accumulation ecotype via a high affini- ty $\mathrm{Cd}$ transporter. Additional studies in yeast showed that IRT1, an iron transporter belonging to the ZIP family, has a broad substrate range and also transports $\mathrm{Zn}$ and possibly Cd (Korshunova et al., 1999; Clemens, 2001). Furthermore, AtNramp3, an Arabidopsis metal transporter involved in iron metal uptake, showed $\mathrm{Cd}^{2+}$ transport activity (Thomine et al., 2000).

\section{Cadmium accumulation and detoxification}

In general, plant accumulation of a given metal is a function of uptake capacity and intracellular binding sites. At every level, concentration and affinities of chelating molecules, as well as the presence and selectivity of transport activities, affect metal accumulation rates (Clemens et al., 2002). The strategies for avoiding heavy metal toxicity are diverse. A first barrier against $\mathrm{Cd}$ stress, operating mainly at the root level, can be the immobilization of Cd by means of the cell wall (Nishizono et al., 1989) and extracellular carbohydrates (mucilage, callose) (Verkleij and Schat, 1990; Wagner, 1993). In roots and leaves of bush bean, $\mathrm{Cd}$ ions seem to be mostly bound by pectic sites and hystidyl groups of the cell wall (Leita et al., 1996). However, the importance of these mechanisms may vary in accordance with the concentration of $\mathrm{Cd}$ supplied, the species involved, the exposure time, etc. (Sanitá di Toppi and Gabrielli, 1999). Preventing Cd ions from entering the cytosol through the action of the plasma membrane, that means exclusion of ions from plant cell walls, could theoretically represent the best defense mechanism. As a matter of fact, in early phases of radish seed germination $\mathrm{Cd}$ seems to enter the cells through $\mathrm{Ca}$ channels in the plasma membrane (Rivetta et al., 1997).

\section{Mycorrizhas}

Mycorrhizas are among the extracellular strategies to avoid metal toxiciy (Marschner, 1995; Jentshcke and Godbold, 2000). However, only few studies have presented direct evidence of the alleviation of metal toxicity by micorrhizal fungus (Leyval et al., 1997; Jentshcke and Godbold, 2000; Schutzendubel and Polle, 2002a), especially those regarding the toxic effects of Al (Schier and McQuattie, 1996), Ni (Jones and Hutchinson, 1986), Zn (Brown and Wilkins, 1985) and Cd (Jentschke et al., 1999). The mechanisms involved in conferring tolerance to heavy metal toxicity has been proved difficult to resolve since large differences in plant and fungal species in the response to metals has been observed (Hall, 2002). In Norway spruce seedlings treated with $\mathrm{Cd}$, a fungus can only increase the tolerance of its host, 
if fungal tolerance exceeds that of the host plant. In that experiment with $\mathrm{Cd}$, the fungus may have been affected by the high $\mathrm{Cd}$ treatment $(5 \mu \mathrm{M})$, thus losing its ability to alleviate $\mathrm{Cd}$ toxicity. However, indirect evidence suggested that the fungus was still viable at $5 \mu \mathrm{M} \mathrm{Cd}$, indicating that the mechanism of amelioration does operate up to a certain threshold of metal exposure only (Jentschke et al., 1999). The mechanisms employed by the fungus at the cellular level are probably similar to those of higher plants. Detoxification of $\mathrm{Cd}$ in Paxillus involotus involved binding of $\mathrm{Cd}$ to the cell walls and accumulation of $\mathrm{Cd}$ in the vacuole (Blaudez et al., 2000).

\section{Cell wall and plasma membranes}

The binding properties of the cell wall and its role in the mechanism of metal tolerance has been controversial (Thurman and Collins, 1983; Verkleij and Schat, 1990). The walls of roots cells are directly exposed to the metals in soil solution. The interaction of the metals with the cell wall has been reported in several articles reviewed by Ernst et al. (1992) but since then, only a few more papers appeared covering this topic. Most of the cell wall-associated heavy metals are bound to polygalacturonic acids, to which the affinity of metal ions vary according to the metal (Ernst et al., 1992). The plasma membrane is the first "living" structure that is target for heavy metal toxicity and, consequently, could also be involved in tolerance. Such toxicity could result from various mechanisms including the oxidation and cross-linking of protein thiols, inhibition of key membrane proteins such as $\mathrm{H}^{+}$-ATPase, or changes in the composition and fluidity of membrane lipids (Meharg, 1993). A direct effect of Cd and $\mathrm{Cu}$ has been reported on the lipid composition of membranes (Fodor et al., 1995; Hernández and Cooke, 1997; Quartacci et al., 2001). Moreover, Cd treatment has been shown to reduce ATPase activity of the plasma membrane fraction of wheat and sunflower roots (Fodor et al., 1995).

\section{Cadmium chelation}

One recurrent general mechanism for heavy metal detoxification in plants and other organisms is the chelation of the metal by a ligand and, in some cases, the subsequent compartmentalization of the ligand-metal complex. Vacuolar compartmentalization prevents the free circulation of $\mathrm{Cd}$ ions in the cytosol and forces them into a limited area (Sanitá di Toppi and Gabrielli, 1999). Several studies have shown that the vacuole is the site of accumulation of a number of heavy metals including $\mathrm{Zn}$ and Cd (Ernst et al., 1992). One example is the accumulation of $\mathrm{Cd}$ and PCs in the vacuole involving an $\mathrm{ABC}$ transporter (Hall, 2002). Several of metal-binding ligands have now been recognized in plants and include organic acids, amino acids, peptides, and polypeptides (Rauser, 1999). Extracellular chelation by organic acids, such as citrate and malate, is important in mechanisms of aluminum tolerance. For example, malate efflux from root apices is stimulated by exposure to aluminum and is correlated with aluminum tolerance in wheat (Delhaize and Ryan, 1995). Some aluminum-resistant mutants of Arabidopsis also have increased organic acid efflux from roots (Larsen et al., 1998). To our knowledge, there are no reports concerning organic acid chelation for $\mathrm{Cd}$ ions

\section{Metallothioneins and Phytochelatins}

The two best-characterized heavy metal-binding polypeptides involved in chelation and sequestration of heavy metals include the metallothioneins (MTs), small, gene-encoded, cysteine-rich polypeptides, and the phytochelatins (PCs), which, in contrast, are enzymatically synthesised, cysteine-rich peptides (Cobbett, 2000). MTs were first identified as Cd-binding proteins in mammalian tissues and are classified based on the arrangement of Cys residues (Robinson et al., 1993; Cobbett and Goldsbrough, 2002). Class I MTs contain 20 highly conserved Cys residues based on mammalian MTs and are widespread in vertebrates. MTs without this strict arrangement of cysteines are referred to as Class II MTs and include all those from plants and fungi, as well as nonvertebrate animals. In this MT classification system, PCs are, somewhat confusingly, described as Class III MTs. (Robinson et al., 1993). After the structures of PCs had been elucidated and it was found that these peptides are distributed widely in the plant kingdom, it was proposed that PCs were the functional equivalent of MTs (Grill et al., 1985). Subsequently, numerous examples of MT-like genes, and in some cases MT proteins, have been isolated from a variety of plant species and it is now apparent that plants express both of these Cys-containing metal-binding ligands. Furthermore, it is likely that the two play relatively independent functions in metal detoxification and/or metabolism (Cobbett and Goldsbrough, 2002). PCs have not been reported in animal species, supporting the notion that in animals, MTs may well perform some of the functions normally contributed by PCs in plants. However, the isolation of the PC synthase gene from plants and the consequent identification of similar genes in animal species, suggests that, at least in some animal species, both these mechanisms contrib- 
ute to metal detoxification and/or metabolism (Cobbett and Goldsbrough, 2002)

Phytochelatins (PCs) are small metal-binding peptides with the structure (g-glu-cys)n-gly, (g-glu-cys)n-bala, (g-glu-cys)n-ser, (g-glu-cys)n-glu, (g-glu-cys)n-gln or (g-glu-cys)n, in which $\mathrm{n}$ varies from 2 to 11 (Grill et al., 1985, 1986a,b). PCs were first identified in 1983 in the yeast Schizosaccharomyces pombe (where they were called cadystins) (Cobbett, 2000), and have subsequently been identified in a wide variety of plant species and in some other microorganisms (Grill et al., 1989; Cobbett and Goldsbrough, 2002 , and references therein). Numerous physiological, biochemical, and genetic studies have confirmed that the tripeptide glutathione (GSH; $\gamma$-Glu-CysGly) is the substrate for PC biosynthesis. Although a number of structural variants of PCs, for example, $(\gamma \text {-GluCys })_{n}-\beta$-Ala, $(\gamma \text {-GluCys })_{n}-$ Ser, and $(\gamma \text {-GluCys })_{\mathrm{n}}$-Glu have been identified in some plant species, they are assumed to be functionally analogous and synthesised via essentially similar biochemical pathways (Rauser, 1999). PC synthesis from GSH is catalysed by a transpeptidase, named phytochelatin synthase (EC 2.3.2.15), which is a constitutive enzyme requiring post-translational activation by heavy metals (Grill et al., 1989; De Knecht et al., 1995; Klapheck et al., 1995). Phytochelatin synthase (PCS) has been shown to be activated only in the presence of heavy metal ions, in particular $\mathrm{Cd}, \mathrm{Ag}, \mathrm{Pb}, \mathrm{Cu}, \mathrm{Hg}, \mathrm{Zn}, \mathrm{Sn}, \mathrm{Au}$, and As, both in vivo and in vitro (Cobbett, 2000 and references therein). The reaction involves the transpeptidation of the $\gamma$ GluCys moiety of GSH onto a second GSH molecule to form $\mathrm{PC}(\mathrm{n}=2)$ or onto a PC molecule to produce a $\mathrm{PC}(\mathrm{n}+1)$ oligomer (Cobbett, 2001). The capacity to synthesize PCs is supposed to be present in all higher plants (Gekeler et al., 1989), the majority of algae (Ahner et al., 1995) and several fungi (Grill et al., 1986b; Miersch et al., 2001). In in vitro reactions, $\mathrm{PC}$ biosynthesis continued until the activating metal ions were chelated either by the PCs formed or by the addition of a metal chelator such as EDTA (Loeffler et al., 1989). PC synthase genes were isolated simultaneously by three research groups using different approaches. Two groups used expression of Arabidopsis and wheat cDNA libraries in S. cerevisiae to identify genes [(AtPCS1 (Vatamaniuk et al., 1999) and TaPCS1 (Clemens et al., 1999), respectively] conferring increased $\mathrm{Cd}$ resistance. The third group identified AtPCS1 through the positional cloning of the CAD1 gene of Arabidopsis (Ha et al., 1999). There is a second PC synthase gene, AtPCS2, in Arabidopsis with significant identity to CAD1/AtPCS1 (Ha et al., 1999). This was an unexpected finding because PCs were not detected in a cad1 mutant after prolonged exposure to $\mathrm{Cd}$, suggesting the presence of only a single active PC synthase in wildtype (Howden et al., 1995). The physiological function of this gene remains to be determined. The significance of PC-Cd complex formation for the detoxification of $\mathrm{Cd}^{2+}$ in plants was supported by the isolation of the Arabidopsis cad1 mutant, which contains wildtype levels of GSH, yet is PC-deficient and is consequently sensitive to $\mathrm{Cd}^{2+}$ (Howden et al., 1995). Kinetic studies using plant cell cultures demonstrated that PC biosynthesis occurs within minutes of exposure to $\mathrm{Cd}$ and is independent of de novo protein synthesis. The enzyme appears to be expressed independently of heavy metal exposure (Cobbett and Goldsbrough, 2002)

Several reports have evidenced that PCs are essential for normal constitutive tolerance to several non-essential metals, particularly Cd. Disruption of the PCS gene in S. pombe resulted in hypersensitivity to $\mathrm{Cd}$ (Clemens et al., 1999; Ha et al., 1999). Moreover, expression of PCS cDNAs from wheat, Arabidopsis, and S. pombe greatly increased Cd tolerance in Saccharomyces cerevisiae, even in mutants deficient in vacuole formation or vacuolar acidification (Clemens et al., 1999). A number of Cd-hypersensitive Arabidopsis mutants appeared to be impaired in PC synthesis (Howden et al., 1995; Cobbett et al., 1998). In addition, tomato cell lines selected for hypertolerance to Cd exhibited enhanced PC synthesis under $\mathrm{Cd}$ exposure, due to increased $\gamma$-glutamyl cysteine synthetase ( $\gamma$-ECS) activity (Chen and Goldsbrough, 1994). Furthermore, overexpression of bacterial $\gamma$-ECS or glutathione synthetase (GS) in Brassica juncea enhanced PC synthesis and Cd tolerance (Zhu et al., 1999a,b).

\section{Heavy metal hyperaccumulator plants}

Although heavy metal hyperaccumulation in plants was first reported in 1865 for Thlaspi calaminare (now Thlaspi caerulescens) (Sachs, 1865), the study of plant heavy metal hyperaccumulation is relatively recent. Brooks et al. (1977) first coined the term 'hyperaccumulator' to define plants with Ni concentrations higher than $1,000 \mu \mathrm{g} \cdot \mathrm{g}^{-1} \mathrm{DW}(0.1 \%)$. This value was not chosen arbitrarily. $\mathrm{Ni}$ is a plant micronutrient and is found in the vegetative organs of most plants in the range of 1-10 $\mu \mathrm{g} . \mathrm{g}^{-1} \mathrm{DW}$ (Assunção et al., 2003). Toxicity occurs at concentrations higher than $10-50 \mu \mathrm{g} . \mathrm{g}^{-1} \mathrm{DW}$ (Marschner, 1995). Although Cd is not an essential or beneficial element for plants, they generally exhibit measurable $\mathrm{Cd}$ concentrations, particularly in roots, but also in leaves, most probably as a result of inadvertent uptake and translo- 
cation (Assunção et al., 2003). A foliar concentration above $100 \mu \mathrm{g} . \mathrm{g}^{-1} \mathrm{DW}(0.01 \%)$ is considered exceptional and is used as a threshold value for $\mathrm{Cd}$ hyperaccumulation (Baker et al., 2000). The metal hyperaccumulation characteristic is not common in terrestrial higher plants and less than $0.2 \%$ of all angiosperms have been identified as metal hyperaccumulators (Baker et al., 2000). Hyperaccumulators of $\mathrm{Ni}, \mathrm{Zn}$, $\mathrm{Cd}, \mathrm{Pb}, \mathrm{Cu}, \mathrm{As}, \mathrm{Co}$ and $\mathrm{Mn}$ have been reported (Brooks et al., 1974; Brown et al., 1995; Baker et al., 2000; Ma et al., 2001). The species belongs to the Brassicaceae or Cruciferae family, which is well represented among the reported hyperaccumulators. T. caerulescens is best known as a $\mathrm{Zn}$ hyperaccumulator, although it also hyperaccumulates $\mathrm{Cd}$ and $\mathrm{Ni}$ (Assunção et al., 2003). Brassica juncea is a heavy metal-accumulator plant with a high biomass, making it a good candidate for application in phytoremediation strategies (Salt et al., 1995b, 1998; Pilon-Smits and Pilon, 2002; Clemens et al., 2002). Recently, transgenic approaches have shown that, in this species, $\mathrm{Cd}$ accumulation may be further increased by ectopic expression of the rate-limiting enzyme for glutathione biosynthesis, namely $\gamma$-glutamylcysteine synthetase (Zhu et al., 1999a,b).

\section{Oxidative stress and ROS generation by cadmium}

Plants are organisms exposed to different kinds of stresses, such as air pollution, drought, temperature, light, heavy metals, salinity, freezing, UV radiation and nutritional limitation. The intoxication with pollutant metals induces oxidative stress because they are involved in several different types of ROS-generating mechanisms (figure 1) (Stohs and Bagchi, 1995). ROS intermediates are partially reduced forms of atmospheric oxygen $\left(\mathrm{O}_{2}\right)$ (Halliwell and Gutteridge, 1999). They typically result from the excitation of $\mathrm{O}_{2}$ to form singlet $\left({ }^{1} \mathrm{O}_{2}\right)$, or from the transfer of one, two or three electrons to $\mathrm{O}_{2}$ to form, respectively, a superoxide radical $\left(\mathrm{O}_{2}{ }^{-}\right)$, hydrogen peroxide $\left(\mathrm{H}_{2} \mathrm{O}_{2}\right)$ or a hydroxyl radical $\left(\mathrm{HO}^{-}\right)$(Dat et al., 2000; Asada, 1999). These radicals occur transiently in aerobic organisms because they are also generated in plant cells during normal metabolic processes, such as respiration and photosynthesis (Asada and Takahashi, 1987). Although some of them may function as important signalling molecules that alter gene expression and modulate the activity of specific defense proteins, all ROS can be extremely harmful to organisms at high concentrations. ROS can oxidize proteins, lipids, and nucleic acids, often leading to alterations in cell structure and mutagenesis (Halliwell and Gutteridge, 1999).
There are many others potential sources of ROS in plants, in addition to those that come from reactions involved in normal metabolism, such as photosynthesis and respiration. The balance between the steady-state levels of different ROS are determined by the interplay between different ROS-producing and ROS-scavenging mechanisms, and can change drastically depending upon the physiological condition of the plant and the integration of different environmental, developmental and biochemical stimuli (Asada and Takahashi, 1987; Asada, 1999; Polle, 2001). A variety of proteins function as scavengers of superoxide and hydrogen peroxide. These include, among others, superoxide dismutase (SOD), catalase (CAT), ascorbate peroxidase (APOX), glutathione reductase (GR), thioredoxin, and the peroxiredoxin family of proteins (Asada, 1999; Mittler, 2002; Bowler et al., 1992). These protein antioxidants are supplemented with a host of nonprotein scavengers, including, but not limited to, intracellular ascorbate and glutathione (Noctor and Foyer, 1998).

The intoxication with pollutant metals induces oxidative stress because they are involved in several different types of ROS-generating mechanisms (Stohs and Bagchi, 1995). For example, transition metals ( (uch as $\mathrm{Fe}^{3+}$ and $\mathrm{Cu}^{2+}$ ) participate in the well-known Haber-Weiss cycle, producing HO- from $\mathrm{O}_{2}-$ and $\mathrm{H}_{2} \mathrm{O}_{2}$ (Winterbourn, 1982). Metals without redox capacity (such as $\mathrm{Cd}^{2+}, \mathrm{Pb}^{2+}$, and $\mathrm{Hg}^{2+}$ ) can enhance the prooxidant status by reducing the antioxidant glutathione (GSH) pool, activating calcium-dependent systems and affecting iron-mediated processes (Pinto et al., 2003). These heavy

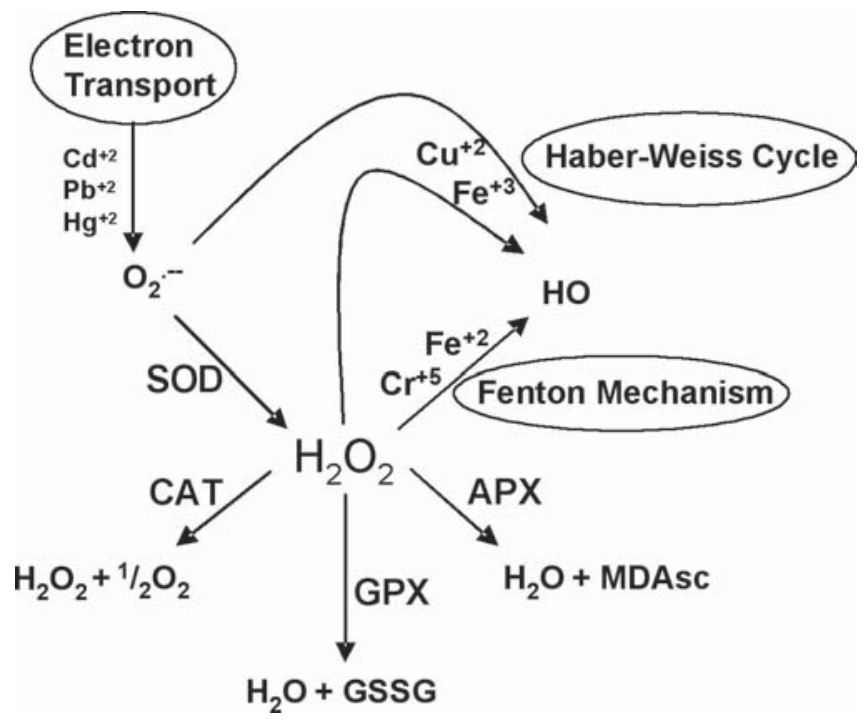

Figure 1. ROS generation by heavy metals. Adapted from Pinto et al. (2003). 
metals can also disrupt the photosynthetic electron chain, leading to $\mathrm{O}_{2}{ }^{-}$and ${ }^{1} \mathrm{O}_{2}$ production (Asada and Takahashi, 1987).

Cd was found to produce oxidative stress (Hendry et al., 1992; Somashekaraiah et al., 1992), but, in contrast with other heavy metals such as $\mathrm{Cu}$, it does not seem to act directly on the production of oxygen reactive species (via Fenton and: or Haber Weiss reactions) (Salin, 1988). As it was previously observed for other stresses, activation or inhibition of antioxidative enzymes depends not only on stress intensity and duration but also on the tissue type and the age of the plant (Sgherri et al., 2001).

Table 1 shows several examples of the oxidative responses to cadmium reported in higher plants. Treatment with Cd stimulated accumulation of lipid peroxides in Pisum sativum (Lozano-Rodríguez et al., 1997; Dixit et al., 2001; Metwally et al., 2004), different barley genotypes (Wua et al., 2003), sunflower seedlings and leaf discs (Groppa et al., 2001; Gallego et al., 1996), Arabidopsis thaliana seedlings (Cho and Seo, 2004) and soybean nodules (Balestrasse et al., 2004), although decreased the rate of lipid peroxidation in peroxisomes of pea plants (Romero-Puertas et al., 1999). No peroxidation was noticed in Cd-exposed plants and hairy roots of Daucus carota (Sanita di Toppi et al., 1998). SOD, GR, APOX, POD and CAT showed variations in their activities that depend on the $\mathrm{Cd}$ concentration and plant species used (Wua et al., 2003; Sandalio et al., 2001; Metwally, 2003, 2004; Gallego et al., 1996; Balestrasse et al., 2003). In Helianthus annuns leaves, Cd decreased GSH content, and decreased or increased the activity of the antioxidative enzymes SOD, CAT, APOX, GR and DHAR, depend- ing on $\mathrm{Cd}$ concentration, the organ used and the age of the plants (Gallego et al., 1996, 1999; Groppa et al., 2001). In Phaseolus vulgaris roots and leaves, $5 \mathrm{mM} \mathrm{Cd}$ enhanced activities of the peroxidases GPOX and APOX, and raised lipid peroxidation (Chaoui et al., 1997). In two species of Alyssum, GR activity increased at $0.02 \mathrm{mM} \mathrm{Cd}$ but decreased at $0.05 \mathrm{mM} \mathrm{Cd}$ (Schickler and Caspi, 1999).

Cadmium treatment induced lipooxygenase, with the simultaneous inhibition of the antioxidative enzymes, SOD and CAT (Somashekaraiah et al., 1992). In particular, CAT activity often decreased following exposure to elevated Cd concentrations (Shim et al., 2003; Dalurzo et al., 1997; Sandalio et al., 2001; Fornazier et al., 2002). However, Vitoria et al. (2001) reported that the activities of CAT, GR and specific isoenzymes of SOD increased in the leaves and roots of a resistant variety of radish, following exposure to increasing (between 0.25 and $1 \mathrm{mM}$ ) concentrations of $\mathrm{Cd}$. Although the concentrations of $\mathrm{Cd}$ used were high when compared to those found in contaminated soils, the same concentrations have also been used in assays with species of Thlaspi that are able to accumulate high concentrations of Cd (Lombi et al., 2000). In soybean nodules and roots, low $\mathrm{Cd}$ concentrations $(50 \mu \mathrm{M})$ induced the antioxidant defenses, which in turn protect nodules and roots against oxidative stress, whereas moderate $(100 \mu \mathrm{M})$ and high $(200 \mu \mathrm{M})$ concentrations of the metal produced oxidative stress in roots, or roots and nodules, respectively (Balestrasse et al., 2001). In several reports, Cd concentrations studied are frequently not realistic when compared with the levels of contamination in the natural environment (Sanitá di Toppi and Gabrielli, 1999). Taking this into account, Milone et al. (2003) presented Cd-induced antiox-

Table 1. Antioxidant enzymes modified in different plant species exposed to variable cadmium concentrations

\begin{tabular}{|c|c|c|c|c|}
\hline $\begin{array}{c}\text { Cadmium } \\
\text { concentration }(\boldsymbol{\mu M})\end{array}$ & Exposure time & Plant species & Antioxidant enzymes modified & References \\
\hline 5 & $10 \mathrm{~d}$ & Pisum sativum & CAT, APOX, GPOX & Metwally et al., 2003 \\
\hline 1 and 10 & $10 \mathrm{~d}$ & Triticum durum & CAT, SOD, APOX, GPOX & Milone et al., 2003 \\
\hline 4 and 40 & $7 \mathrm{~d}$ & Pisum sativum & CAT, SOD, APOX, GPOX & Dixit et al., 2001 \\
\hline 5 and 50 & $48 \mathrm{~h}$ & Populus canescens & CAT, SOD, APOX, GR, MDAR & Schützendübel and Polle, 2002 \\
\hline 50 & $21 \mathrm{~d}$ & Phragmites australis & CAT, SOD, APOX, GR & Ianelli et al., 2002 \\
\hline 50,100 and 200 & $48 \mathrm{~h}$ & Glycine max & CAT, SOD, APOX & Balestrasse et al., 2001 \\
\hline 500 & $12 \mathrm{~h}$ & Helianthus annuus & CAT, SOD, APOX, GR, DHAR & Gallego et al., 1996 \\
\hline 100 and 500 & $20 \mathrm{~d}$ & Oryza sativa & CAT, SOD, GPOX & Shah et al., 2001 \\
\hline 300 and 500 & $21 \mathrm{~d}$ & Arabidopsis thaliana & CAT, SOD, APOX, GPOX, GR & Cho and Seo, 2004 \\
\hline 2000 and 5000 & $0-96 \mathrm{~h}$ & Saccharum officinarum & CAT, SOD, GR & Fornazier et al., 2002 \\
\hline 5000 & $0-24 \mathrm{~h}$ & Oryza sativa & CAT, SOD, APOX, GPOX, GR & Hsu and Kao, 2004 \\
\hline
\end{tabular}


idative responses in wheat treated with realistic concentrations of $\mathrm{Cd}$ (up to $10 \mu \mathrm{M} \mathrm{Cd}$ ). In this work, SOD, APOX and CAT were inhibited in the roots of the most sensitive cultivar, Adamello, while SOD was scarcely affected in both roots and leaves of Adamello and the most tolerant cultivar, Ofanto. Lipid peroxidation and $\mathrm{H}_{2} \mathrm{O}_{2}$ levels, SOD, CAT, APOX and GR activities increased in pea roots and leaves under Cd stress (Dixit et al., 2001), while APOX and CAT decreased at high $\mathrm{Cd}$ concentrations (Sandalio et al., 2001). A severe suppression of SOD and CAT, and almost complete loss of APOX activities after $48 \mathrm{~h}$ of exposure to $50 \mu \mathrm{M} \mathrm{Cd}$ was observed in pine roots (Schutzendubel and Polle, 2001).

Cd-induced inhibition of APX and CAT was also associated with $\mathrm{H}_{2} \mathrm{O}_{2}$ accumulation and growth retardation in the poplar roots (Schutzendubel and Polle, 2002b). Cho and Seo (2004) reported that Cd-induced oxidative stress in Arabidopsis is due to $\mathrm{H}_{2} \mathrm{O}_{2}$ accumulation. Romero-Puertas et al. (2004) studied the involvement of $\mathrm{H}_{2} \mathrm{O}_{2}$ and $\mathrm{O}_{2}{ }^{--}$in the signalling events that lead to the variation of the transcript levels of CAT, GR and $\mathrm{CuZn-SOD}$ in pea plants under Cd stress.

Thiols possess strong antioxidative properties, and they are consequently able to counteract oxidative stress (Pichorner et al., 1993). Groppa et al. (2001) and Gallego et al. (1996) reported a Cd-induced decay in GSH content in sunflower plants or leaf discs, respectively. There are numerous papers reporting $\mathrm{Cd}$-induced depletion of GSH in several plant species (Rauser et al., 1995; Dixit et al., 2001; Balestrasse et al., 2001). However, GSH increased in Phragmites australis roots and leaves, treated either with 50 $\mu \mathrm{M}$ Cd (Ianelli et al., 2002), or 50 and $100 \mu \mathrm{M} \mathrm{Cd}$ (Pietrini et al., 2003). Cadmium-induced depletion of GSH has been mainly attributed to phytochelatin synthesis (Grill et al., 1985). In tobacco leaves, PC-heavy metal complexes have been reported to be accumulated in the vacuole (VogeliLange and Wagner, 1990). Also in Avena sativa, PC-Cd complexes have been shown to be transported across the tonoplast (Salt and Rauser, 1995). In two varieties of two wheat species, a significant increase in total PC accumulation with increasing Cd exposure has been reported (Stolt et al., 2003). The decline in the levels of GSH might also be attributed to a decreased GR activity (Dixit et al., 2001), an increased utilization for ascorbate synthesis or for a direct interaction with metals like Cd (Pietrini et al., 2003) or xenobiotics. The variety of responses to $\mathrm{Cd}$-induced oxidative stress is probably related not only to the levels of Cd supplied, but also to the plant species, the age of the plant and duration of treatment. Table 1 shows antioxidant enzyme variations reported by several authors using different $\mathrm{Cd}$ concentrations, exposure times and plant species.

There is a growing interest in problems concerning heavy metal contamination of cultivated lands and little is known regarding metal homeostasis and tolerance at the organismic level. For that reason, it is essential to clarify those problems related to metal transport, accumulation, detoxification and tolerance, and in this sense, it would be of enormous interest to use of model systems other than plants, such as Saccharomyces pombe and Saccharomyces cereviciae, as well as the molecular analysis of hyperaccumulators like Arabidopsis halleri and some of the Thlaspi species. Very little is known about the biochemistry of metal homeostasis factors. Physical interaction of transporters, chelators and chaperones is likely to play an important role. An improved knowledge in these crucial areas will help to further elucidate the molecular mechanism that lie beyond plant metal tolerance and homeostasis.

Acknowledgements: MP Benavides; SM Gallego and ML Tomaro are career investigators of the Consejo Nacional de Investigaciones Científicas y Técnicas (CONICET).

\section{REFERENCES}

Ahner BA, Kong S, Morel FMM (1995) Phytochelatin production in marine algae. 1. An interspecific comparison. Limnol. Oceanog. 40:649-657.

Alcantara E, Romera FJ, Cañete M, De La Guardia MD (1994) Effects of heavy metals on both induction and function of root $\mathrm{Fe}(\mathrm{III})$ reductase in Fe-deficient cucumber (Cucumis sativus L.) plants. J. Exp. Bot. 45:1893-1898.

Asada K (1999) The water-water cycle in chloroplasts: scavenging of active oxygen and dissipation of excess photons. Ann. Rev. Plant Physiol. Plant Mol. Biol. 50:601-639.

Asada K, Takahashi M (1987) Production and scavenging of active oxygen in photosynthesis. In: Kyle DJ, Osmond C, Arntzen CJ (eds.), Photoinhibition, pp. 227-297. Elsevier, New York.

Assunção AGL, Schat H, Aarts MGM (2003) Thlaspi caerulescens, an attractive model species to study heavy metal hyperaccumulation in plants. New Phytol. 159:351-360

Baker AJM, McGrath SP, Reeves DR, Smith JAC (2000) Metal hyperaccumulator plants: a review of the ecology and physiology of a biological resource for phytoremediation of metal-polluted soils. In: Terry N, Bañuelos G (eds), Phytoremediation of contaminated soils and water, pp.171-188. CRC Press, Boca Raton, FL, USA.

Baker AJM, Ewart K, Hendry GAF, Thorpe PC, Walker PL (1990) The evolutionary basis of cadmium tolerance in higher plants. In: 4th International Conference on Environmental Contamination, pp.23-29. Barcelona, Spain. 
Balestrasse KB, Benavides MP, Gallego SM; Tomaro ML (2003) Effect on cadmium stress on nitrogen metabolism in nodules and roots of soybean plants. Func. Plant Biol. 30:57-64.

Balestrasse KB, Gallego SM, Tomaro ML (2004) Cadmiuminduced senescence in nodules of soybean (Glycine max L.) plants. Plant Soil 262:373-381.

Balestrasse KB, Gardey L, Gallego SM, Tomaro ML (2001) Response of antioxidant defence system in soybean nodules and roots subjected to cadmium stress. Aust. J. Plant Physiol. 28:497-504.

Barceló J, Poschenrieder C, Andreu I, Gunsé B (1986) Cadmium-induced decrease of water stress resistance in bush bean plants (Phaseolus vulgaris L. cv. Contender). I. Effects of $\mathrm{Cd}$ on water potential, relative water content and cell wall elasticity. J. Plant Physiol. 125:17-25.

Barceló J, Poschenrieder C (1990) Plant water relations as affected by heavy metal stress: a review. J. Plant Nutr. 13:1-37.

Bert V, Meerts P, Saumitou-Laprade P, Salis P, Gruber W, Verbruggen N (2003) Genetic basis of Cd tolerance and hyperaccumulation in Arabidopsis halleri. Plant Soil 249:9-18

Bhattacharya M, Chaudhuri MA (1995) Heavy metal ( $\mathrm{Pb}^{2+}$ and $\mathrm{Cd}^{2+}$ ) stress-induced damages in Vigna seedlings and possible involvement of phytochelation-like substances in mitigation of heavy metal stress. Indian J. Environ. Bull. 33:236-238.

Bingham FT, Page AL, Mahler RJ, Ganje TJ (1976) Yield and cadmium accumulation of forage species in relation to cadmium content of sludge-amended soil. J. Environ. Qual. 5:57-59.

Blaudez D, Botton B, Chalot M (2000) Cadmium uptake and subcellular compartmentation in the ectomycorrhizal fungus Paxillus involutus. Microbiology 146:1109-1117.

Blum WH (1997) Cadmium uptake by higher plants. In: Proceedings of extended abstracts from the Fourth International Conference on the Biogeochemistry of Trace Elements, pp.109-110, Berkeley, USA. University of California.

Bowler C, Van Montagu M, Inze D (1992) Superoxide dismutase and stress tolerance. Annu. Rev. Plant Physiol. Plant Mol. Biol. 43: 83-116.

Brooks RR (1998) Plants that hyperaccumulate heavy metals. CAB International, Wallingford, UK.

Brooks RR, Lee J, Jaffré T (1974) Some New Zealand and New Caledonian plant accumulators of nickel. J. Ecol. 62: 493-499.

Brooks RR, Lee J, Reeves RD, Jaffré T (1977) Detection of nickeliferous rocks by analysis of herbarium specimens of indicator plants. J. Geochem. Exp. 7:49-57.

Brown JC, Jones WE (1975) Heavy metal toxicity in plants 1. A crisis in embryo. Commun. Soil. Sci. Plant Anal. 6: 421-438.

Brown MT, Wilkins DA (1985) Zinc tolerance of mycorrhizal Betula. New Phytol. 99:101-106.

Brown SL, Chaney RL, Angle JS, Baker AJM (1995) Zinc and cadmium uptake by hyperaccumulator Thlaspi caerulescens grown in nutrient solution. Soil Sci. Soc. Am. J. 59:125-133.
Cataldo DA, Garland TR, Wildung RE (1983) Cadmium uptake kinetics in intact soybean plants. Plant Physiol. 73: 844-848.

Chaoui A, Mazhoudi S, Ghorbal MH, El Ferjani E (1997) Cadmium and zinc induction of lipid peroxidation and effects on antioxidant enzyme activities in bean (Phaseolus vulgaris L). Plant Sci. 127:139-147.

Chen JJ, Goldsbrough PB (1994) Increased activity of $\gamma$ glutamylcysteine synthetase in tomato cells selected for cadmium tolerance. Plant Physiol. 106:233-239.

Chiy PC, Phillips CJC (1999) The effects of mild water stress and soil type on the responses of grass and clover to sodium fertilizer. J. Sci. Food Agric. 79:1399-1405.

Cho M, Chardonnens AN, Dietz KJ (2003) Differential heavy metal tolerance of Arabidopsis halleri and Arabidopsis thaliana: a leaf slice test. New Phytol. 158:287-293.

Cho U, Seo N (2004) Oxidative stress in Arabidopsis thaliana exposed to cadmium is due to hydrogen peroxide accumulation, Plant Sci. 168:113-120.

Clarkson DT, Luttge U (1989) Mineral nutrition. Divalent cations, transport and compartmentalization. Prog. Bot. 51:93-112.

Clemens S (2001) Molecular mechanisms of plant metal tolerance and homeostasis. Planta 212:475-486.

Clemens S, Kim EJ, Neumann D, Schroeder JI (1999) Tolerance to toxic metals by a gene family of phytochelatin synthases from plants and yeast. EMBO J. 18:33253333.

Clemens S, Palmgreen MG, Kramer U (2002) A long way ahead: understanding and engineering plant metal accumulation. Trends Plant Sci. 7:309-315.

Cobbett CS, May MJ, Howden R, Rolls B (1998) The glutathione-deficient, cadmium-sensitive mutant, cad2-1, of Arabidopsis thaliana is deficient in $\gamma$-glutamylcysteine synthetase. Plant J. 16:73-78.

Cobbett CS (2000) Phytochelatins and their roles in heavy metal detoxification. Plant Physiol. 123:825-832.

Cobbett CS (2001) Heavy Metal Detoxification in Plants: Phytochelatin. Biosynthesis and Function. IUBMB Life 51:183-188.

Cobbett C and Goldsbrough P (2002) Phytochelatins and Metallothioneins: Roles in Heavy Metal Detoxification and Homeostasis. Ann. Rev. Plant Physiol. Plant Mol. Biol. 53:159-82.

Costa G, Morel JL (1994) Water relations, gas exchange and amino acid content in Cd-treated lettuce. Plant Physiol. Biochem. 32:561-570.

Dalurzo HC, Sandalio LM, Gomez M, Del Río LA (1997) Cadmium infiltration of detached pea leaves: effect on its activated oxygen metabolism. Phyton-Ann. Rei. Bot. 37: 59-64.

Das P, Samantaray S, Rout GR (1997) Studies on cadmium toxicity in plants: a review. Environ. Pollution 98:29-36.

Dat JF, Van Breusegem F, Vandenabeele S, Vranová E, Van Montagu M, Inzé D (2000) Dual action of active oxygen species during plant stress responses. Cell. Mol. Life Sci. 57:779-795. 
De Filippis LF, Ziegler H (1993) Effect of sublethal concentrations of zinc, cadmium and mercury on the photosynthetic carbon reduction cycle of Euglena. J. Plant Physiol.142:167-172.

De Knecht JA, Van Baren N, ten Bookum WM, Wong Fong Sang HW, Koevoets PLM, Schat H, Verkleij JAC (1995) Synthesis and degradation of phytochelatins in cadmium sensitive and cadmium-tolerant Silene vulgaris. Plant Sci. 106:9-18.

Degreave N (1981) Carcinogenis, teratogenic and mutagenic effects of cadmium. Mutation Res. 86:115-122.

Delhaize EP, Ryan R (1995) Aluminum toxicity and tolerance in plants. Plant Physiol. 107:315-321.

Dietz KJ, Baier M, Kramer U (1999) Free radicals and reactive oxygen species as mediators of heavy metal toxicity in plants. In: Prasad MNV, Hagemeyer J (eds), Heavy metal stress in plants: from molecules to ecosystems, pp.73-97. Springer-Verlag, Berlin.

Dixit V, Pandey V, Shyam R (2001) Differential oxidative responses to cadmium in roots and leaves of pea (Pisum sativum L cv. Azad). J. Exp. Bot. 52:1101-1109.

Duxbury T (1985) Ecological aspects of heavy metal responses in microorganisms. Adv. Microb. Ecol. 8:185-235.

Ernst WHO, Verkleij JAC, Schat H (1992) Metal tolerance in plants. Acta Bot. Neerl. 41:229-248.

Fodor A, Szabó-Nagy A, Erdei L (1995) The effects of cadmium on the fluidity and $\mathrm{H}^{+}$-ATPase activity of plasma membrane from sunflower and wheat roots. J. Plant Physiol. 14:787-792.

Fornazier RF, Ferreira RR, Vitória AP, Molina SMG, Lea PJ, Azevedo RA (2002) Effects of cadmium on antioxidant enzyme activities in sugar cane. Biol. Plant. 45:91-97.

Foy CD, Chaney RL, White MC (1978) The physiology of metal toxicity in plants. Ann. Rev. Plant Physiol. 29:11-566.

Gallego SM, Benavides MP, Tomaro ML (1996) Effect of heavy metal ion excess on sunflower leaves: evidence for involvement of oxidative stress. Plant Sci. 121:151-159.

Gallego SM, Benavides MP, Tomaro ML (1999) Effect of cadmium ions on antioxidant defense system in sunflower cotyledons. Biol. Plant. 42:49-55.

Gekeler W, Grill E, Winnacker EL, Zenk MH (1989) Survey of the plant kingdom for the ability to bind heavy metals through phytochelatins. Zeitschrift Naturforsch. 44: 361369.

Goldbol DL, Hutterman A (1985) Effect of zinc, cadmium and mercury on root elongation on Picea abies (Karst.) seedlings and the significance of these metals to forest die-back. Environ. Pollution 38:375-381.

Grill E, Winnacker E-L, Zenk MH (1985) Phytochelatins: the principal heavy-metal complexing peptides of higher plants. Science 230: 674-676.

Grill E, Gekeler W, Winnacker EL, Zenk MH (1986a) Homophytochelatins are heavy metal-binding peptides of homoglutathione containing Fabales. FEBS Letters 205:47-50.

Grill E, Winnacker EL, Zenk MH (1986b) Synthesis of seven different homologous phytochelatins in metal-exposed Schizosaccharomyces pombe cells. FEBS Letters 197:115-120.
Grill E, Loffler S, Winnacker EL, Zenk, M H (1989) Phytochelatins, the heavy-metal-binding peptides of plants, are synthesized from glutathione by a specific $\gamma$-glutamylcysteine dipeptidyl transpeptidase (phytochelatin synthase). Proc. Natl. Acad. Sci. USA 86: 6838-6842.

Groppa MD, Tomaro ML, Benavides MP (2001) Polyamines as protectors against cadmium or copper-induced oxidative damage in sunflower leaf discs. Plant Sci. 161:481-488.

Guerinot ML (2000) The ZIP family of metal transporters. Biochim. Biophys. Acta 1465:190-198.

Ha SB, Smith AP, Howden R, Dietrich WM, Bugg S (1999) Phytochelatin synthase genes from Arabidopsis and the yeast, Schizosaccharomyces pombe. Plant Cell 11:1153-64.

Haghiri F (1973) Plant uptake of cadmium as influenced by cation exchange capacity, organic matter, zinc and soil temperature. J. Environ. Qual. 2:93-96.

Hall JL (2002) Cellular mechanisms for heavy metal detoxification and tolerance. J. Exp. Bot. 53:1-11.

Halliwell B, Gutteridge JMC (1999) Free Radicals in Biology and Medicine. 3rd ed. Oxford University Press, New York.

Hart JJ, Welch RM, Norvell WA, Sullivan LA, Kochian LV (1998) Characterization of cadmium binding, uptake, and translocation in intact seedlings of bread and durum wheat cultivars. Plant Physiol. 116: 1413-1420.

Heiss S, Wachter A, Bogs J, Cobbett C, Rausch T (2003) Phytochelatin synthase (PCS) protein is induced in Brassica juncea leaves after prolonged Cd exposure. J. Exp. Bot. 54:1833-1839.

Hendry GAF, Baker AJM, Ewart CF (1992) Cadmium tolerance and toxicity, oxygen radical processes and molecular damage in cadmium-tolerant and cadmium-sensitive clones of Holcus lanatus. Acta Bot. Neerl. 41:271-281.

Hernández LE, Cárpena-Ruiz R, Garate A (1996) Alterations in the mineral nutrition of pea seedlings exposed to cadmium. J. Plant Nutr. 19:1581-1598.

Hernández LE, Cooke DT (1997) Modification of the roots plasma membrane lipid composition of cadmium-treated Pisum sativum. J. Exp. Bot. 48:1375-1381.

Hinesly TD, Redberg KE, Pites RI, Ziegler EL (1984) Cadmium and Zinc uptake by corn (Zea mays L) with repeated applications of sewage sludge. J. Agric. Food Chem. 32:155-163.

Hirsch RE, Lewis BD, Spalding EP, Sussman MR (1998) A role for the AKT1 potassium channel in plant nutrition. Science 280:918-921.

Howden R, Goldsbrough PB, Andersen CR, Cobbett CS (1995) Cadmium-sensitive, cad1 mutants of Arabidopsis thaliana are phytochelatin deficient. Plant Physiol. 107:1059-1066

Hsu YT, Kao CH (2004) Cadmium toxicity is reduced by nitric oxide in rice leaves. Plant Growth Regul. 42: 227-238.

Iannelli MA, Pietrini F, Fiore L, Petrilli L, Massacci A (2002) Antioxidant response to cadmium in Phragmites australis plants. Plant Physiol. Biochem. 40:977-982.

Jentschke G, Winter S, Godbold DL (1999) Ectomycorrhizas and cadmium toxicity in Norway spruce seedlings. Tree Physiol. 19:23-30 
Jentshcke G, Godbold DL (2000) Metal toxicity and ectomycorrhizas. Physiol. Plant. 109:107-116.

Jones MD, Hutchinson TC (1986) The effect of mycorrhizal infection on the response of Betula papyrifera to nickel and copper. New Phytol. 102:429-442.

Klapheck S, Schlunz S, Bergmann L (1995) Synthesis of phytochelatins and homo-phytochelatins in Pisum sativum L. Plant Physiol. 107:515-521.

Korshunova YO, Eide D, Clark WG, Guerinot ML, Prakasi HB (1999) The IRT1 protein from Arabidopsis thaliana is a metal transporter with a broad substrate range. Plant Mol. Biol.40: 37-44.

Küpper H, Lombi E, Zhao FJ, McGrath SP (2000) Cellular compartmentation of cadmium and zinc in relation to other elements in the hyperaccumulator Arabidopsis halleri. Planta 212:75-84.

Lane TW, Morel FM (2000) A biological function for cadmium in marine diatomeas. Proc. Natl. Acad. Sci. USA 97: 4627-4631.

Larsen PB, Degenhardt J, Stenzler LM, Howell SH, Kochian LV (1998) Aluminum-resistant Arabidopsis mutant that exhibit altered patterns of aluminum accumulation and organic acid release from roots. Plant Physiol. 117:9-18.

Lasat MM, Pence NS, Garvin DF, Ebbs SD, Kochian LV (2000) Molecular physiology of zinc transport in the Zn hyperaccumulator Thlaspi caerulescens. J. Exp. Bot. 51:71-79.

Leita L, De Nobili M, Cesco S, Mondini C (1996) Analysis of intercellular cadmium forms in roots and leaves of bush bean. J. Plant Nutr. 19:527-533.

Leyval C, Turnau K, Haselwandter R (1997) Effect of heavy metal pollution on mycorrhizal colonization and function: physiological, ecological and applied aspects. Mycorrhiza 7:139-153.

Loeffler S, Hochberger A, Grill E, Winnacker EL, Zenk MH (1989) Termination of the phytochelatin synthase reaction through sequestration of heavy metals by the reaction product. FEBS Lett. 258:42-46.

Lombi E, Zhao FJ, Dunham SJ, McGrath SP (2000) Cadmium accumulation in populations of Thlaspi caerulescens and Thlaspi goesingense. New Phytol. 145:11-20.

Lozano-Rodríguez E, Hernández LE, Bonay P, Cárpena-Ruiz RO (1997) Distribution of Cd in shoot and root tissues of maize and pea plants: physiological distribution. J. Exp. Bot. 48:123-128.

Ma LQ, Komar KM, Tu C, Zhang W, Cai Y, Kennelley ED (2001) A fern that hyperaccumulates arsenic. Nature 409: 579 .

Macfarlane GR, Burchett MD (2001) Photosynthetic pigments and peroxidase activity as indicators of heavy metal stress in the greymangrove, Avicennia marina (Forsk.) Vierh. Mar. Pollut. Bull. 42:233-40.

Marschner H (1995) Mineral nutrition of higher plants, $2^{\text {nd }}$ edn. Academic Press, London.

Mathys W (1975) Enzymes of heavy metal-resistant and nonresistant populations of Silene cucubalus and their interactions with some heavy metals in vitro and in vivo. Physiol. Plant. 33:161-165.
Meharg AA (1993) The role of plasmalemma in metal tolerance in angiosperms. Physiol. Plant. 88:191-198.

Metwally A, Finkemeier I, Georgi M, Dietz KJ (2003) Salicylic acid alleviates the cadmium toxicity in barley seedlings. Plant Physiol. 132:272-281.

Metwally A, Safronova VI, Belimov AA, Dietz KJ (2004) Genotypic variation of the response to cadmium toxicity in Pisum sativum L. J. Exp. Bot. 56:167-178 in press.

Miersch J, Tschimedbalshir M, Barlocher F, Grams Y, Pierau B, Schierhorn A, Kraus GJ (2001). Heavy metals and thiol compounds in Mucor racemosus and Articulospora tetracladia. Mycol. Res. 105:883-889.

Milone MT, Sgherri C, Clijters H, Navari-Izzo F (2003) Antioxidative responses of wheat treated with realistic concentrations of cadmium. Environ. Exp. Bot. 50 265-273.

Mittler R (2002) Oxidative stress, antioxidants and stress tolerance. Trends Plant Sci. 7: 405-410.

Moral R, Palacios G, Gómez I, Navarro-Pedreno J, Mataix J (1994) Distribution and accumulation of heavy metals (Cd, Ni and Cr) in tomato plant. Fresenius Environ. Bull. 3:395-399.

Moreno JL, Hernandez T, Garcia C (1999). Effects of a cadmium-containing sewage sludge compost on dynamics of organic matter and microbial activity in an arid soils. Biol. Fert. Soils 28:230-237.

Mukherjee A, Sharma A, Talukdeer G (1984) Effects of cadmium on cellular systems in higher organisms. The Nucleus 27:121-139.

Niess DH (1999) Microbial heavy-metal resistance. Applied Microbiol. Biotech. 51:730-750.

Nishizono H, Kubota K, Suzuki S, Ishii F (1989) Accumulation of heavy metals in cell walls of Polygonum cuspidatum roots from metalliferous habitats. Plant Cell Physiol. 30:595-598.

Noctor G, Foyer CH (1998) Ascorbate and glutathione: keeping active oxygen under control. Ann. Rev. Plant Physiol. Plant Mol. Biol. 49:249-279.

Obata H, Umebayashi M (1997) Effects of cadmium on mineral nutrient concentrations in plants differing in tolerance for cadmium. J. Plant Nutr. 20:97-105.

Pence NS, Larsen PB, Ebbs SD, Letham DLD, Lasat MM, Garvin DF, Eide D, Kochian LV (2000) The molecular physiology of heavy metal transport in the $\mathrm{Zn} / \mathrm{Cd}$ hyperaccumulator Thlaspi caerulescens. Proc. Nat. Acad. Sci. USA 97: 4956-4960.

Pichorner H, Korori SAA, Thur A, Ebermann R (1993) The two and the four electron transfer to molecular oxygenmediated by plant peroxidase in the presence of thiols. In: Welinder KG, Rasmussen SK, Penel C, Greppin H (eds.), Plant Peroxidases: Biochemistry and Physiology, pp.131136. University of Geneva.

Pietrini F, Iannelli MA, Pasqualini S, Massacci A (2003) Interaction of Cadmium with glutathione and photosynthesis in developing leaves and chloroplasts of Phragmites australis (Cav.) Trin. ex Steudel. Plant Physiol. 133:829-837.

Pilon-Smits E, Pilon M (2002) Phytoremediation of metals using transgenic plants. Crit. Rev. Plant Sci. 21:439-456. 
Pinto E, Sigaud-Kutner TCS, Leitão MAS, Okamoto OK, Morse D, Colepicolo P (2003) Heavy metal-induced oxidative stress in algae. J. Phycol. 39:1008-1018.

Pinto AP, Mota AM, de Varennes A, Pinto FC (2004) Influence of organic matter on the uptake of cadmium, zinc, copper and iron by sorghum plants. Sci. Tot. Environ 326:239-247.

Polle A. (2001) Dissecting the superoxide dismutase-ascorbate peroxidase-glutathione pathway in chloroplasts by metabolic modeling. Computer simulations as a step towards flux analysis. Plant Physiol. 126:445-462

Poschenrieder C, Gunsé B, Barceló J (1989) Influence of cadmium on water relations, stomatal resistance, and abscisic acid content in expanding bean leaves. Plant Physiol. 90: 1365-1371.

Prasad MNV (1999) Metallothioneins and metal binding complexes in plants. In: Prasad MNV, Hagemeyer J (eds), Heavy metal stress in plants: from molecules to ecosystems, pp.5172. Springer Verlag, Berlin, Heidelberg.

Quartacci MF, Cosi E, Navari-Izzo F (2001) Lipids and NADPH-dependent superoxide production in plasma membranes vesicles from roots of wheat grown under copper deficiency or excess. J. Exp. Bot. 52:77-84.

Ramos I, Esteban E, Lucena JJ, Garate A (2002) Cadmium uptake and subcellular distribution in plants of Lactuca sp. Cd-Mn interaction. Plant Sci. 162:761 -767.

Rauser WE (1995) Phytochelatins and related peptides: structure, biosynthesis, and function. Plant Physiol. 109: 1141-1149.

Rauser WE (1999) Structure and function of metal chelators produced by plants: the case for organic acids, amino acids, phytin and metallothioneins. Cell Biochem. Biophys. 31:19-48.

Rivetta A, Negrini N, Cocucci M (1997) Involvement of $\mathrm{Ca}^{2+}$ calmodulin in $\mathrm{Cd}^{2+}$ toxicity during the early phases of radish (Raphanus sativus L.) seed germination. Plant Cell Environ. 20:600-608.

Robinson NJ, Tommey AM, Kuske C, Jackson PJ (1993) Plant metallothioneins. Biochem. J. 295:1-10.

Romero-Puertas MC, McCarthy I, Sandalio LM, Palma JM, Corpas FJ, Gomez M, del Rio LA (1999) Cadmium toxicity and oxidative metabolism of pea leaf peroxisomes. Free Rad. Res. 31:25-31.

Romero-Puertas MC, Rodríguez-Serrano M, Corpas FJ, Gomez M, del Rio LA, Sandalio LM. (2004) Cadmiuminduced subcellular accumulation of $\mathrm{O}_{2}{ }^{--}$and $\mathrm{H}_{2} \mathrm{O}_{2}$ in pea leaves. Plant Cell Environ. 27:1122-1134.

Sachs J (1865) Handbuch der Experimental-Physiologie der Pflanzen. Verlag von Wilhelm Engelmann, Leipzig, Germany.

Salin ML (1988) Toxic oxygen species and protective systems of the chloroplasts. Physiol. Plant. 72:681-689.

Salt DE, Rauser WE, (1995) MgATP-dependent transport of phytochelatins across the tonoplast of oat roots. Plant Physiol. 107:1293-1301.

Salt DE, Prince RC, Pickering IJ, Raskin I (1995a) Mechanisms of cadmium mobility and accumulation in Indian mustard. Plant Physiol. 109:427-433.
Salt DE, Blaylock M, Kumar NPBA, Dushenkov V, Ensley BD, Chet I, Raskin I (1995b) Phytoremediation: a novel strategy for the removal of toxic metals from the environment using plants. Biotechnol. 13:468-474.

Salt DE, Smith RD, Raskin I (1998) Phytoremediation. Ann. Rev. Plant Physiol. Plant Mol. Biol. 49:643-668.

Sandalio LM, Dalurzo HC, Gomez M, Romero-Puertas MC, del Río LA (2001) Cadmium-induced changes in the growth and oxidative metabolism of pea plants. J. Exp. Bot. 52: 2115-2126.

Sanitá di Toppi L, Gabbrielli R (1999) Response to cadmium in higher plants. Environ. Exp. Bot. 41:105-130.

Schickler H, Caspi H (1999) Response of antioxidant enzymes to nickel and cadmium stress in hyperaccumulator plants of the genus Alyssum. Physiol. Plant. 105:39-44.

Schier G, McQuattie C (1996) Response of ectomycorrhizal and nonmycorrhizal pitch pine (Pinus rigida) seedlings to nutrient supply and aluminium: Growth and mineral nutrition. Can. J. For. Res. 26:2145-2152.

Schützendübel A, Schwanz P, Teichmann T, Gross K, Langenfeld-Heyser R, Godbold A, Polle A (2001) Cadmium-induced changes in antioxidative systems, $\mathrm{H}_{2} \mathrm{O}_{2}$ content and differentiation in pine (Pinus sylvestris) roots. Plant Physiol. 127: 887-898.

Schutzendubel A, Polle A (2002a) Plant responses to abiotic stresses: heavy-metal induced oxidative stress and protection by mycorrhization. J. Exp. Bot. 53:1351-1365.

Schutzendubel A, Polle A (2002b) Cadmium and $\mathrm{H}_{2} \mathrm{O}_{2}$-induced oxidative stress in Populus $x$ canescens roots. Plant Physiol. Biochem. 40: 577-584.

Senden MHMN, Van Paassen FJM, Van der Meer AJGM, Wolterbeek HT (1992) Cadmium-citric acid xylem cell wall interactions in tomato plants. Plant Cell Environ. 15:71-79.

Senden MHMN, Van der Meer AJGM, Verburg TG, Wolterbeek HT (1994) Effects of cadmium on the behaviour of citric acid in isolated tomato xylem cell walls. J. Exp. Bot. 45:597-606.

Sgherri CLM, Milone AMT, Clijsters H, Navari-Izzo F (2001) Antioxidative enzymes in two wheat cultivars, differently sensitive to drought and subjected to sub-symptomatic copper doses. J. Plant Physiol. 158:1439-1447.

Shaw BP (1995) Effect of mercury and cadmium on the activities of antioxidative enzymes in the seedlings of Phaseolus aureus. Biol. Plant. 37:587-596.

Shah K, Kumar RG, Verma S, Dubey RS (2001) Effect of cadmium on lipid peroxidation, superoxide anion generation and activities of antioxidant enzymes in growing rice seedlings. Plant Sci. 161:1135-1144.

Shim IS, Momose Y, Yamamoto A, Kim DW, Usui K (2003) Inhibition of catalase activity by oxidative stress and its relationship to salicylic acid accumulation in plants. Plant Growth Regul. 39:285-292.

Somashekaraiah BV, Padmaja K, Prasad ARK (1992) Phytotoxicity of cadmium ions on germinating seedlings of mung bean (Phaseolus vulgaris): involvement of lipid peroxides in chlorophyll degradation. Physiol. Plant. 85:85-89. 
Stobart AK, Griffits W, Bukhari IA, Sherwood RP (1985) The effect of $\mathrm{Cd}^{2+}$ on the biosynthesis of chlorophyll in leaves of barley. Physiol. Plant. 63:293-298.

Stohs SJ, Bagchi D (1995) Oxidative mechanisms in the toxicity of metal ions. Free Rad. Biol. Med. 18:321-336

Stolt JP, Sneller FEC, Bryngelsson T, Lundborg T, Schat H (2003) Phytochelatin and cadmium accumulation in wheat. Environ. Exp. Bot. 49:21-28.

Street JJ, Lindsay WL, Sabey BR (1977) Solubility and plant uptake by cadmium in soils amended with cadmium and sewage sludge. J. Environ. Qual. 6:72-77.

Tester M, Leigh RA (2001) Partitioning of nutrient transport processes in roots. J. Exp. Bot. 52:445-457.

Thomine S, Wang R, Ward JM, Crawford NM, Schroeder JI (2000) Cadmium and iron transport by members of a plant metal transporter family in Arabidopsis with homology to Nramp genes. Proc. Natl. Acad. Sci. USA 97: 4991-4996.

Thurman DA, Collins JCL (1983) Metal tolerance mechanisms in higher plants-review. In: Proc. Int. Conf. Heavy Metals in the Environment. Heidelberg, CEP Consultans, Edimburg, pp.298-300.

Tudoreanu L, Phillips CJC (2004) Modelling cadmium uptake and accumulation in plants. Adv. Agron. 84:121-157.

Tyler G, Pahlsson AM, Bengtsson G, Baath E, Tranvik L (1989) Heavy metal ecology and terrestrial plants, microorganisms and invertebrates: a review. Water, Air Soil Pollut. 47:189-2150.

Van Assche F, Clijsters H (1990) Effects of metals on enzyme activity in plants. Plant Cell Environ. 13:195-206.

Vatamaniuk OK, Mari S, Lu Y-P, Rea PA (1999) AtPCS1, a phytochelatin synthase from Arabidopsis: isolation and in vitro reconstitution. Proc. Natl. Acad. Sci. USA 96:7110-1579.

Verkleij JAC, Schat H (1990) Mechanisms of metal tolerance in higher plants. In: Shaw J. (eds), Heavy metal tolerance in plants: evolutionary aspects, pp.179-193. CRC Press, Boca Raton.
Vitoria AP, Lea PJ, Azevedo RA (2001) Antioxidant enzymes responses to cadmium in radish tissues. Phytochemistry 57:701-710.

Vogeli-Lange F, Wagner G (1990) Subcellular localization of cadmium and cadmium-binding peptides in tobacco leaves. Implication of a transport function for cadmium binding peptides. P lant Physiol. 92:1086-1093.

Wagner GJ (1993) Accumulation of cadmium in crop plants and its consequences to human health. Adv. Agron. 51: 173-212.

Weast RC (1984) CRC Handbook of Chemistry and Physics. $64^{\text {th }}$ edn. CRC Press, Boca Raton.

Williams LE, Pittman JK, Hall JL (2000) Emerging mechanisms for heavy metal transport in plants. Biochim. Biophys. Acta 1465:104-126.

Winterbourn CC (1982) Superoxide-dependent formation of hydroxyl radicals in the presence of iron salts is a feasible source of hydroxyl radicals in vivo. Biochem. J. Lett. 205: 461-463.

Wua F, Zhang G, Dominy P (2003) Four barley genotypes respond differently to cadmium: lipid peroxidation and activities of antioxidant capacity. Environ. Exp. Bot. 50: 63-78

Yang MG, Lin XY, Yang XE (1998) Impact of Cd on growth and nutrient accumulation of different plant species. Chin. J. Appl. Ecol. 19:89-94.

Zhu YL, Pilon-Smits EAH, Jouanin L, Terry N (1999a). Overexpression of glutathione synthetase in Indian mustard enhances cadmium accumulation and tolerance. Plant Physiol. 119: 3-79.

Zhu YL, Pilon-Smits EAH, Jouanin L, Terry N (1999b) Cadmium tolerance and accumulation in Indian mustard is enhanced by overexpressing $\gamma$-glutamylcysteine synthetase. Plant Physiol. 121:1169-1177. 